\title{
Epidemiological features of chronic cystitis in the capital megapolis
}

\author{
N.O. Saidakova ${ }^{1}$, orcid: 0000-0002-7174-9540, e-mail: ju.patent@gmail.com \\ V.P. Stus ${ }^{2}$, orcid: 0000-0002-4539-8126, e-mail: viktor.stus@gmail.com \\ O.V. Shulyak 1, orcid: 0000-0002-6920-2212, e-mail: avshulyak@hotmail.com \\ N.V. Havva ${ }^{2}$, orcid: 0000-0001-6986-0920, e-mail: natalihavva@gmail.com \\ L.M. Startseva 1, orcid: 0000-0002-5264-142X, e-mail: uronauka@ukr.net \\ 1 SI "Institute of Urology of the National Academy of Medical Sciences of Ukraine" \\ 2 Dnipro State Medical University
}

\section{Keywords:}

chronic cystitis, prevalence, morbidity, women, men, capital

\section{For citation:}

ДСТУ 8302 2015:

Saidakova N.O., Stus V.P., Shulyak O.V., Havva N.V., Startseva L.M. Epidemiological features of chronic cystitis in the capital megapolis. Уpoлогія. 2021. Т. 25, № 2. С. 123-129. DOI: $10.26641 / 2307-5279.25 .2 .2021$. 238234.

\section{APA:}

Saidakova, N.O., Stus, V.P., Shulyak, O.V., Havva, N.V., \& Startseva, L.M. (2021). Epidemiological features of chronic cystitis in the capital megapolis. Urologiya, 25(2), 123-129. DOI: 10.26641/2307-5279.25.2.2021.238234.

\section{SUMMARY}

The paper presents the results of the analysis for 2008-2017 of the prevalence and incidence of chronic cystitis in the adult population of Kiev based on the data of state, sectoral statistical reports (F.F. No. 12, 20). Two five-year periods are highlighted, the justification for which was the well-known territorial changes in the country; the corresponding indicators served as a comparison, which made it possible to identify the features of the dynamics of the studied processes.

As a result of 10 years of observation, it was revealed that for the city of Kiev, which ranks second in the structure of the prevalence and incidence of chronic cystitis in Ukraine, a decrease in the number of registered patients (by 7.3\%) with a simultaneous increase in newly diagnosed patients (by $15.6 \%$; by $25.6 \%$ of men and $13.2 \%$ of women), in contrast to their overall growth in the country as a whole (by $0.4 \%$ and $2.8 \%$, respectively). Prevalence rates (per 100 thousand) after an increase in the first five years are replaced by a decrease in the next period (621.2 to 687.9 versus 627.8 to 533.4). Among women, they were 3.5-4.8 times large; in $2017-862.8$ versus 176.6 among men. The peculiarity of the incidence was manifested by its increase among women and men in 2013-2017 against the background of a decrease in the previous years; in 2017, the indicators per 100 thousand reached 88.5; among women -127.2 , men -41.5 .

The observed situation of an increase in the incidence of chronic cystitis among the adult population of the capital with a simultaneous decrease in the prevalence allows us to evaluate it as a result of the provided adequate specialized care and, at the same time, indicates the need to study the causes, negative factors, as the basis for the improvement and implementation of disease prevention. 


\section{INTRODUCTION Вступ}

In the current conditions of development and continuation of reforms in the health care system of Ukraine, the issue of providing the population with quality and effective medical care, which should be patient-oriented, preventive, able to respond immediately to common socially significant diseases, is acute. The justification is the provision of priority implementation of the identified issues at the regional level. In the light of the above-mentioned infections of the lower urinary tract, due to their negative impact on physical and psycho-emotional health, belong to the category of such pathologies. It is generally recognized that they pose a serious problem in urology, primarily due to their tendency to recur, as well as the multifaceted causes of development, which determines the prevalence among people of different ages of both sexes [1,2]. However, the literature data indicate a clear predominance of women at a younger age (up to 30 years) with a surge in premenopausal morbidity. Men are more likely to get sick in old age. Although the preconditions for such a situation are widely known, as well as the main links of the mechanism of cystitis recurrence, the number of appeals and hospitalizations for pathology is not reduced [3, 4, 5]. Therefore, the current situation and needs to be resolved, dictates the actualization of the definition of ways to improve it. In view of the above, one of them is the possession of specific data on the dynamics of the prevalence, incidence of chronic cystitis (CC) of the adult population in a particular administrative territory. By the nature of changes in the relevant indicators, their ratio will be possible to assess the effectiveness of already involved clinical and organizational measures and identify problematic issues in the system of providing such patients with medical care, including specialized care $[6,7]$.

The aim of the work: to conduct a trend comparative analysis of the prevalence and incidence of chronic cystitis in women and men in Kyiv and to identify features of changes in the nature of allUkrainian processes.

\section{MATERIALS AND METHODS Матеріали і методи дослідження}

The paper presents a ten-year analysis (20082017) of the prevalence and incidence of chronic cystitis according to state, sectoral statistical reports of medical institutions of the Ministry of Health of Ukraine and data of the State Statistics Service of Ukraine (FF № 12, 20). A special feature was the study of these processes among the adult population of different sexes in Kyiv. The capital of Ukraine, as a megalopolis, with the allocation of two periods of five years (2008-2012 and 2013-2017), attracts the attention of its multimillion population, a developed network of treatment and prevention facilities, including urological services, as well as scientific institutions with sufficient material and technical equipment.It is also characterized by socio-economic problems of the general economic crisis. It should be noted that in assessing the individual parameters, they were compared with the relevant data not only with the all-Ukrainian, but also Dni propetrovsk,Lviv and Kharkiv regions, which are close to the capital in terms of population; $7.6 \%, 6.0 \%, 6.5 \%$ of the total adult population of Ukraine lived in them, respectively, in Kyiv $-6.8 \%$. However, there was a difference in its composition by gender. In Lviv there were more men $(46.5 \pm 0.05 \%)$, in Dni propetrovsk women $(55.6 \pm 0.04 \%)$,in the capital and Kharkiv region almost equally (women 55\% and $54.7 \%$ respectively).

Absolute and intensive coefficients per 100 thousand of the corresponding population were analyzed; if necessary, average values with their standard error were used; the standard approach (absolute increase/ decrease; increase/decrease rate) as well as the Student's criterion when comparing two statistical parameters were used to process the time series data.

\section{RESULTS AND DISCUSSION Результати та їх обговорення}

A 10-year analysis (2008-2017) of epidemiological processes of chronic cystitis (CC) in Ukraine revealed their nature, features and differences in prevalence and incidence, including regional. The main general trend was the increase in registered patients by $0.4 \%$ from 2008 to 65,239 in 2017 due to women, the number of which increased by $3.9 \%$ to 50,290 , while men decreased by $9.7 \%$ to 14,949 , respectively. At the same time, similar changes were observed in the number of cases with the first diagnosis, namely: by $2.8 \%$ to 15112 ; by $5.0 \%$ to 11295 and $(-3.4 \%)$ to 3817 patients. The advantage of their growth rate compared to its magnitude among those who are registered is alarming and indicates the need to update preventive measures. A regional assessment of the situation revealed that the South-Eastern region was in the lead in both distribution structures, in which the proportion of patients was, over the years, in the range of $29.7-37.4 \%$ and $25.0-52.0 \%$, respectively. The second place that attracts attention belonged to the city of Kyiv. It concentrates 20$23.6 \%$ of cases of all registered in Ukraine patients with CC. However, the difference in dynamics was 
manifested by their decrease by $7.3 \%$ from 2008 to 13055 in 2017, the process of which was more pronounced among men (by $29.4 \%$ to 1879 ) against women (by $2.8 \%$ to 11176 ). Another picture was observed in the analysis of newly diagnosed patients with CC. Their number increased by $15.6 \%$ by 2089 in 2017 against 10 consecutive years, due to the mutual process with greater intensity among men (by $25.6 \%$ to 442 ) against women (by $13.2 \%$ to 1647). The illustration to the presented information is contained in Table 1.

This is especially important given the presence in the capital of a developed network of treatment and prevention facilities with sufficient logistics and dictates the need for careful study of the causes of the situation with the adoption of urgent measures by health authorities. Before further presentation of the results of a detailed study of changes in epidemiological processes taking into account gender, study periods in Kyiv, the above data led to a comparative analysis with those that took place in other, similar to the capital, administrative territories, the number and composition of adults. These include Dni propetrovsk, Lviv and Kharkiv regions, where they lived respectively $7.6 \%, 6.0 \%, 6.5 \%$ of the total (34403861); in the city of Kyiv $-6.8 \%$.
An interest in the aspect of the study is the gender distribution of the population. It is presented as follows: in Kyiv the share of men was $45.0 \%$, women $55.0 \%$, in Dnipropetrovsk region $-44.4 \%$ and $55.6 \%$, Lviv $-46.5 \%$ and $53.5 \%$, Kharkiv $45.3 \%$ and $54.7 \%$. Against the background of these data, the percentage of registered patients with CC in Kyiv is worrying, which in 2017 was equal to $20 \%$, while in Dnipropetrovsk region $-12.2 \%$, Kharkiv $-11.7 \%$, and in Lviv only $6.0 \%$, the lack of logical consistency is confirmed by indicators calculated per 100 thousand population. Their values, respectively, were $553.4 ; 299.6 ; 338.6$ and 189.9 . There is even more disagreement among men. They accounted for: in Kyiv - 14.4\%, Dnipropetrovsk region $-33.0 \%$, Kharkiv $-29.7 \%$ and Lviv $13.0 \%$; in intensive quantities $-176.6 ; 222.3 ; 221.6$ and 52.9 (per 100 thousand). That is, the given example does not assume the relationship between the population and the number of registered patients. This position is confirmed by the analysis of patients with a first diagnosis. Thus, their share in the capital accounted for $13.8 \%$, Dnipropetrovsk region $12.0 \%$, Lviv $-9.0 \%$, Kharkiv $-6.1 \%$; per 100 thousand: $88.5 ; 64.5 ; 66.4$ and 40.9 . Men suffering from CC, respectively: $11.6 \%, 15.9 \%, 7.3 \%$ and $6.0 \%$,

TABLE 1. Dynamics of patients with chronic cystitis in Kyiv in terms of Ukraine, taking into account gender

\begin{tabular}{|c|c|c|c|c|c|c|c|c|c|c|c|c|}
\hline \multirow{4}{*}{ Years } & \multicolumn{6}{|c|}{ A total amount of registered patients } & \multicolumn{6}{|c|}{ Patients were detected for the first time } \\
\hline & \multicolumn{3}{|c|}{ Ukraine } & \multicolumn{3}{|c|}{ Kyiv } & \multicolumn{3}{|c|}{ Ukraine } & \multicolumn{3}{|c|}{ Kyiv } \\
\hline & Total & Inclu & ading & Total & Incluc & ling & Total & Inclu & ding & Total & Incluc & ding \\
\hline & amou & women & nen & amo & women & nen & amo & women & nen & amo & 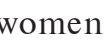 & men \\
\hline \multirow{2}{*}{2008} & 94 & 48385 & $16562 /$ & 14089/ & $11497 /$ & $2663 /$ & \multirow{2}{*}{14703} & 10751/ & $3952 /$ & $1807 /$ & $1455 /$ & $352 /$ \\
\hline & & & 25,5 & 21,7 & 23,8 & 16,1 & & 73,2 & 26,8 & 12,2 & 13,5 & 9,0 \\
\hline \multirow{2}{*}{2009} & 68666 & 50805 & 17961/ & $15151 /$ & 13362/ & $2593 /$ & \multirow{2}{*}{15020} & 10722/ & $4298 /$ & $1610 /$ & $1310 /$ & $300 /$ \\
\hline & & & 26,1 & 22,1 & 26,0 & 14,4 & & 71,4 & 28,6 & 10,7 & 12,2 & 7,0 \\
\hline \multirow{2}{*}{2010} & 72215 & 55887 & $16328 /$ & 15172/ & 12963/ & 2209/ & \multirow{2}{*}{20926} & 11154/ & 9772/ & $1558 /$ & $1252 /$ & $306 /$ \\
\hline & & & 22,6 & 21,0 & 23,2 & 13,5 & & 53,3 & 46,7 & 7,4 & 11,2 & 3,1 \\
\hline \multirow{2}{*}{2011} & 69368 & 52797 & $16571 /$ & $15535 /$ & $12840 /$ & $2332 /$ & \multirow{2}{*}{14762} & 10909/ & $3853 /$ & $1352 /$ & 1044/ & $308 /$ \\
\hline & & & 23,9 & 22,4 & 24,3 & 14,0 & & 73,9 & 26,1 & 9,1 & 12,4 & 8,0 \\
\hline \multirow{2}{*}{2012} & 67295 & 51370 & $15925 /$ & 15942/ & 13368/ & $2574 /$ & \multirow{2}{*}{14826} & 11113/ & $3713 /$ & $1649 /$ & $1300 /$ & $349 /$ \\
\hline & & & 23,7 & 24 & 26,0 & 16,2 & & 75,0 & 25,0 & 11,1 & 11,7 & 9,4 \\
\hline \multirow{2}{*}{2013} & 67756 & 51361 & $16395 /$ & $14658 /$ & $12526 /$ & $2132 /$ & \multirow{2}{*}{14797} & 10915/ & $3882 /$ & $1433 /$ & $1133 /$ & $300 /$ \\
\hline & טס ודוט & ה1501 & 24,2 & 23,6 & 24,4 & 13,0 & & 73,3 & 26,2 & 9,7 & 10,4 & 7,7 \\
\hline \multirow{2}{*}{2014} & 65014 & 48602 & $16412 /$ & 14907/ & $12220 /$ & $2687 /$ & \multirow{2}{*}{14562} & $10680 /$ & $3828 /$ & $1696 /$ & $1276 /$ & $420 /$ \\
\hline & 05014 & 48002 & 25,2 & 22,8 & 25,1 & 16,4 & & 73,7 & 26,3 & 11,6 & 12,0 & 11,0 \\
\hline \multirow{2}{*}{2015} & 65213 & 49818 & 15397/ & $14145 /$ & 11961/ & 2184/ & \multirow{2}{*}{15448} & 11580/ & $3868 /$ & $1811 /$ & $1470 /$ & $341 /$ \\
\hline & 05215 & & 23,6 & 21,7 & 24,0 & 14,2 & & 75,0 & 25,0 & 11,7 & 12,7 & 8,8 \\
\hline \multirow{2}{*}{2016} & 62194 & 48397 & 13797/ & 13234/ & 11325/ & 1909/ & \multirow{2}{*}{14176} & 10937/ & $3139 /$ & $1736 /$ & $1377 /$ & $359 /$ \\
\hline & & & 22,0 & 21,3 & 23,4 & 13,8 & & 77,8 & 22,1 & 12,2 & 12,6 & 11,4 \\
\hline \multirow[t]{2}{*}{2017} & 65239 & 50290 & 14949/ & 13055/ & 11176/ & 1879/ & \multirow{2}{*}{15112} & 11295/ & $3817 /$ & 2089/ & $1647 /$ & $442 /$ \\
\hline & צנבנט & 30290 & 23,0 & 20,0 & 22,2 & 12,6 & & 74,7 & 25,3 & 13,8 & 14,6 & 11,6 \\
\hline
\end{tabular}

Note: \% relative to data in Ukraine as a whole (in the numerator - absolute values; in the denominator specific). 
and the incidence rates were $-41.5 ; 51.4 ; 29.7$ and 22.2 (per 100 thousand). Thus, it becomes obvious that each specific situation has its reasons, among which one, but not the only, is the organization and quality of medical care. It will help to change the careful study of the situation on the ground, which, together with the identification of other negative factors, will allow to take targeted measures, justify the adoption of appropriate management decisions. That is, the possession of objective information, according to statistical analysis, is a motivating prerequisite for directing efforts to preserve the health of the population.

According to the above information, the importance of a separate territory in terms of improving the health care system has crystallized, including confirmation of the allocation of Kyiv with its socio-economic features, strong scientific base and developed network of medical and practical institutions.

Next, we present the results of the analysis of the dynamics of the prevalence, incidence of CC among the adult population of the capital, taking into account gender and study periods. To this end, we return to Table 1 and comment in the specified plan its data. Thus, their analysis shows a clear advantage of women, whose share is significantly higher in the capital. In particular, among the registered patients with $\mathrm{CC}$, the indicator was in the range of 81.6-88.6\%, while in Ukraine -74.0 $77.4 \%$; on average $84.5 \pm 1.6 \%$ against $75.5 \pm 1.9 \%$; $\mathrm{p}<0.05$. Among the cases with the first diagnosis $75.2-81.2 \%$ against $53.3-77.8 \%$ respectively and $79.2 \pm 2.6 \%$ against $72.1 \pm 3.1 \%$ respectively; $p<0.05$. In the structure of the distribution of women registered in the country, Kyiv took 2nd place, men -4 th after the South-Eastern and Western regions, while among the first identified patients the first - fourth, men - fifth place. Attention is drawn to the sufficient variability by year and sex of the absolute values of registered and newly diagnosed patients both in Ukraine and in Kyiv.

This prompted the calculation of their average values, which allows you to more clearly define the typical feature of the processes. Figures presented in Table 2 and 3 show the difference between the two five-year plans.

It was as follows. The first feature of the second period (2013-2017) was a significant decrease in the number of registered patients with $\mathrm{CC}$ in both Ukraine and Kyiv, which was typical for both sexes and more intense in the capital. Otherwise, it manifested itself in patients with a first diagnosis. This period was characterized by a probable increase, with the exception of men in the country as a whole. The above results of the analysis of the dynamics of absolute values were supplemented by similar ones based on the study of intensive indicators per 100 thousand of the relevant population (hereinafter, for convenience, we present their values directly). In fig. 1 and 2 present a time series of levels of prevalence and incidence of CC in Kyiv, respectively, taking into account of gender.

At once it is necessary to specify similarity of the general character of changes, their consistency with those which are revealed on absolute data. A comparative analysis of prevalence indicators (Fig. 1) clearly shows how their growth during 2008-2012 among the adult population due to its female gender is replaced by their annual decrease

TABLE 2. Dynamics of registered patients with chronic cystitis by study periods in Ukraine and Kyiv $(\mathrm{M} \pm \mathrm{m})$

\begin{tabular}{|c|c|c|c|c|c|c|}
\hline \multirow{2}{*}{$\begin{array}{l}\text { Admistrative } \\
\text { units }\end{array}$} & \multicolumn{2}{|c|}{ Periods } & \multicolumn{2}{|c|}{ Women } & \multicolumn{2}{|c|}{ Men } \\
\hline & I & II & I & II & I & II \\
\hline Kyiv & $15178280 \pm 280$ & $13400 \pm 409 *$ & $12806 \pm 62,0$ & $11842 \pm 27,0^{*}$ & $2474 \pm 177$ & $2158 \pm 131$ \\
\hline Ukraine & $68498 \pm 845$ & $65084 \pm 800 *$ & $51829 \pm 223$ & $49694 \pm 99,0^{*}$ & $16670 \pm 312$ & $15390 \pm 444^{*}$ \\
\hline
\end{tabular}

Note: $*$ - the difference between the indicators is significant between periods; $\mathrm{p}>0,05$.

TABLE 3. Dynamics of the number of patients with chronic cystitis with the first diagnosis in Ukraine and Kyiv, taking into account of gender $(\mathrm{M} \pm \mathrm{m})$

\begin{tabular}{lcccccc}
\hline \multicolumn{1}{c}{$\begin{array}{c}\text { Admistrative } \\
\text { units }\end{array}$} & I & II & I & II & I & II \\
\hline Kyiv & $1595 \pm 65,0$ & $1753 \pm 80,0^{*}$ & $1272 \pm 12,0$ & $1380 \pm 69^{*}$ & $323 \pm 10,2$ & $372 \pm 23,6^{*}$ \\
Ukraine & $14447 \pm 158$ & $14819 \pm 99^{*}$ & $10929 \pm 81$ & $11439 \pm 123^{*}$ & $5118 \pm 960$ & $3707 \pm 130$ \\
\hline
\end{tabular}

Note: $* /$ the difference between the indicators for periods is reliable; $p<0,05$. 


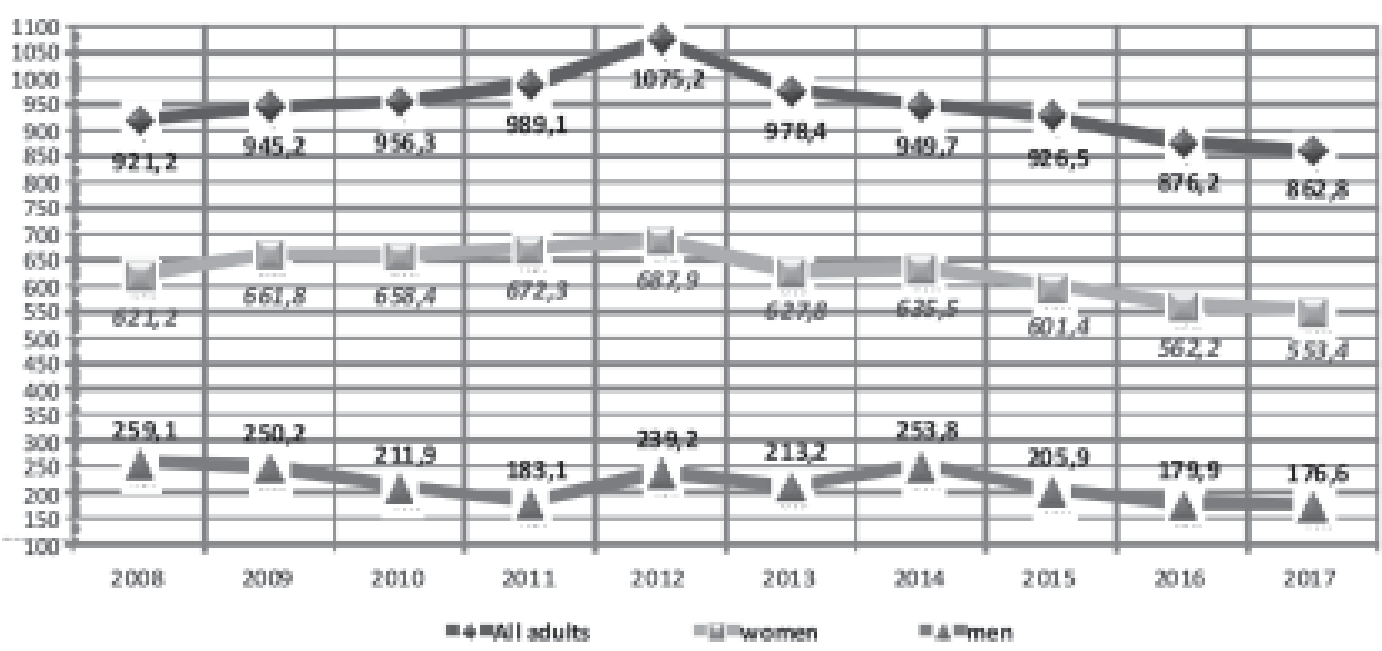

FIGURE 1. Dynamics of levels of prevalence of chronic cystitis among the adult population of Kyiv, taking into account of gender (per 100 thousand of the corresponding population)

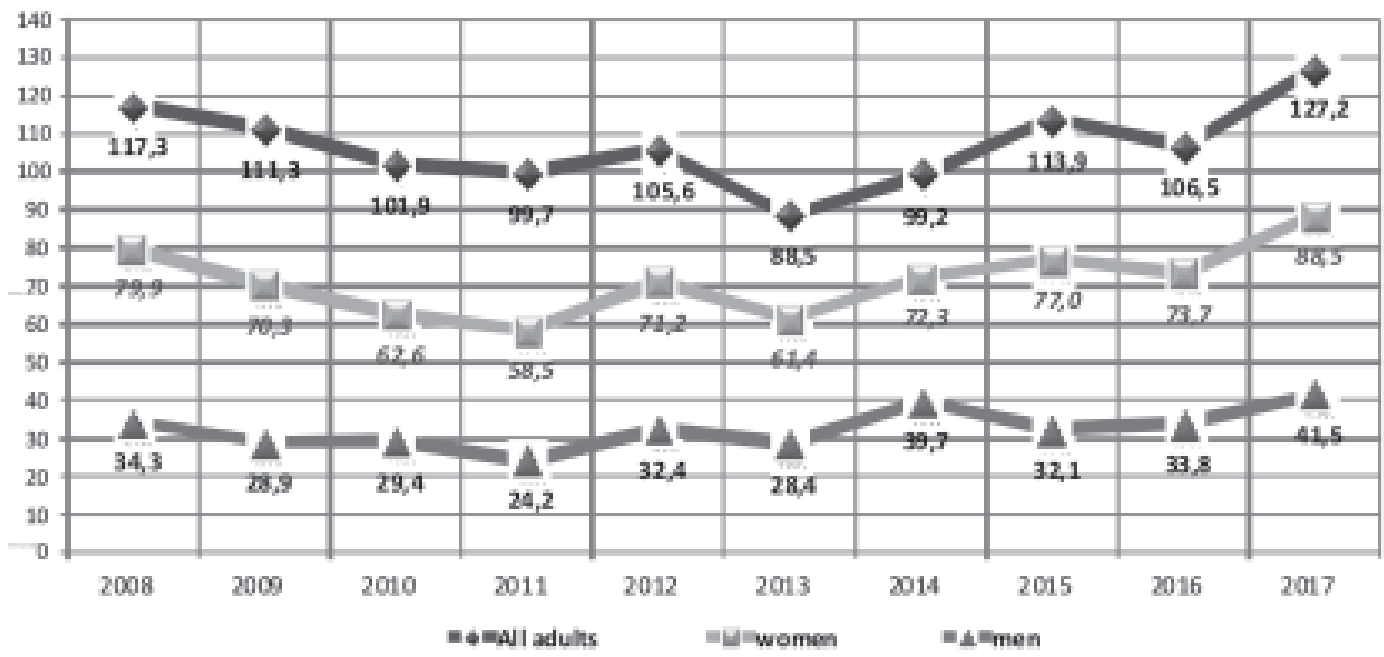

FIGURE 2. Dynamics of chronic cystitis incidence rates among the adult population in Kyiv, taking into account of gender (per 100 thousand people)

in 2013-2017, while for men this trend was observed for 10 years. As a result, in 2017 the prevalence of $\mathrm{CC}$ among the adult population in Kyiv was 553.4 against 627.8 in 2013 and 621.2 in 2008 , among females 862.8 against 978.4 and 921 , respectively, 2, male -176.6 against 213.2 and 259.1, respectively. It is noteworthy that the prevalence of CC is 3.5 to 4.8 times higher among women than men. It persists in morbidity with a slightly smaller difference between them (3-3.5 times). This is confirmed by specific data can be seen in Fig. 2. In addition, it clearly shows the increase in the incidence of CC among the population of Kyiv in the last five years (2013-2017) against the background of a decrease in the previous ones. As a result, in 2017 its levels were among the total adult population 88.5 against 61.4 in 2013 and 79.9 in 2008, among women 127.2 against 88.5 and 117.3 , respectively, men -41.5 versus 28.4 and 34.3 .
Thus, the results of the study show, on the example of $\mathrm{CC}$, the need to study the nature of changes in the prevalence, incidence of certain diseases in certain administrative territories. Not only the duration of observation, but also the possibility of clarifying the features of certain periods in the comparative aspect should be considered justified. Such information can be the basis for conclusions about the activities of medical care in relation to a certain category of patients, and the ratio of the dynamics of prevalence and morbidity objectify the adoption of priority measures to improve the real situation. As for the city of Kyiv itself, the increase in morbidity rates among both females and males in 2013-2017 against the background of a simultaneous decrease in prevalence suggests the adequacy of treatment methods with positive results. However, more importantly, there is an urgent need to study the causes, identify negative factors that 
contribute to the disease, as a basis for the development and implementation of prevention measures.

\section{CONCLUSIONS Висновки}

1. It was found that in Kyiv, which ranks second in the structure of prevalence and incidence of chronic cystitis in Ukraine, in contrast to the allUkrainian process to the growth of registered and newly diagnosed patients (for 10 years by $0.4 \%$ and $2.8 \%$, respectively), mainly due to women, there was a decrease in the former by $7.5 \%$ (men by $29.4 \%$, women by $2.8 \%$ ) with a simultaneous, mutual for both sexes, an increase in the latter (by $15.6 \%$ and by $25.6 \%$ of men and $13.2 \%$ of women).

2. It is established that the increase in the prevalence of chronic cystitis (per 100 thousand corresponding population) in the capital during 2008-2012 (from 621.2 to 687.9) is replaced by their decline in the next five years (from 627.8 to 553.4). Indicators among women during all years of study exceeded their values among men by $3.5-$ 4.8 times; they were 862.8 and 176.6 in 2017 , respectively, against 921.2 and 259.1 in 2008 .

3. An increase in the incidence of chronic cystitis among both sexes in the last five years (20132017) and a decrease in the previous ones; in 2017 in Kyiv the indicator was (per 100 thousand) 88.5 against 79.9 in 2008; among women -127.2 against 117.3 , men -41.5 against 34.3 . The peculiarity of higher incidence rates among women than men in 3-3.5 times is confirmed.

4. Proven typical for the capital increase in the incidence of chronic cystitis among the adult population of both sexes in 2013-2017, while reducing the prevalence allows to consider the result of adequate specialized care and, at the same time, indicates the urgent need to study the causes, negative factors basics of implementation of disease prevention measures.

\section{СПИСОК ЛІТЕРАТУРИ References}

1. Кульчевеня Е.В., Неймарк А.И., Цуканов А.Ю., Ярин Г.Ю. Современные подходы к диагностике острого цистита и оценке качества его лечения. Урология. 2020. № 3. С. 22-25.

2. Bonkat G., Bartoletti R., Bruyere F., Cai T., Geerlings S.E. et al. Urological infections EAU guidelines. 2020. URL: http://uroweb.org/guideline/ urologicalinfertions.

3. Кульчевеня Е.В. Новый подход к пониманию патогенеза и к лечению инфекционно-вос- палительных заболеваний мочеполовой системы. Урология. 2020. № 5. С. 99-105.

4. Flores-Mireles A.L., Walker J.N., Caparon M., Hultgren S.J. Urinary trat infections: epidemiology, mechanisms of infection and treatment options. Nat Rev Microbiol. 2015. Vol. 13. P. 269-284. Doi: 10.1038/ nrmicro3432.

5. Нікітін О.Д. Сучасний підхід до інтравезикальної терапії хронічного циститу. Здоровье мужччин. 2015. № 4. С. 17-20.

6. Пасєчніков С.П. Цистит: етіопатогенез, класифікація, клінічна картина, діагностика, лікування. Український медичний часопис. 2016. № 4(114). C. 34-37.

7. Gupta K. Urinary tract infections: diagnostic and management issues. Infect. Dis. Clin. North Am. 2014. Vol. 28, No. 1. P. 9-10.

\section{REFERENCES \\ Список літератури}

1. Bonkat, G., Bartoletti, R., Bruyere, F., Cai, T., Geerlings, S.E., et al. (2020). Urological infections EAU guidelines. Uroweb.org. Retrieved from http:// uroweb.org/guideline/urologicalinfertions.

2. Flores-Mireles, A.L., Walker, J.N., Caparon, M., \& Hultgren, S.J. (2015). Urinary trat infections: epidemiology, mechanisms of infection and treatment options. Nat Rev Microbiol., 13, 269-284. Doi: $10.1038 /$ nrmicro3432.

3. Gupta, K. (2014). Urinary tract infections: diagnostic and management issues. Infect. Dis. Clin. North Am., 28, 1, 9-10. 


\section{РЕФЕРАТ}

Епідеміологічні особливості хронічного циститу у столичному мегаполісі

\author{
Н.О. Сайдакова, В.П. Стусь, \\ О.В. Шуляк, Н.В. Гавва, \\ Л.М. Старцева
}

У роботі представлені результати аналізу за 2008-2017 роки поширеності та захворюваності на хронічний цистит дорослого населення м.Києва на основі даних державних, галузевих статистичних звітів (Ф.Ф. № 12, 20). Виділено два п'ятирічних періоди, обгрунтуванням для чого були відомі територіальні зміни в країні; відповідні показники служили в якості порівняння, що дозволяло виявити особливості динаміки досліджуваних процесів.

У результаті 10-річного спостереження виявлено, що для м.Києва, який займає друге місце в структурі поширеності та захворюваності хронічного циститу в Україні, характерне зменшення кількості зареєстрованих хворих (на 7,3\%) з одночасним збільшенням вперше виявлених (на $15,6 \%$; на $25,6 \%$ чоловіків і на $13,2 \%$ жінок) на відміну від загального їх приросту в цілому по країні (на $0,4 \%$ і на 2,8\% відповідно). Показники поширеності (на 100 тис.) Після підвищення в перші п'ять років змінюються зниженням в наступному періоді (621,2 до 687,9 проти 627,8 до 533,4). Серед жінок вони були великими в $3,5-4,8$ разу; в 2017 р. $-862,8$ проти 176,6 серед чоловіків. Особливість захворюваності проявилася iï збільшенням серед жінок і чоловіків за 2013-2017 роки на тлі зменшення в попередні; в 2017 р. показники на 100 тис. досягали 88,5 ; серед жінок - 127,2, чоловіків - 41,5.

Простежена ситуація підвищення рівня захворюваності на хронічний цистит серед дорослого населення столиці при одночасному зниженні поширеності дозволяє оцінювати ii як результат наданої адекватної спеціалізованої допомоги i, разом з тим, вказує на необхідність вивчення причин, негативних чинників, як основи вдосконалення та впровадження профілактики захворювання.

Ключові слова: хронічний цистит, поширеність, захворюваність, жінки, чоловіки, столиця.

\section{PEФEPAT}

\section{Эпидемиологические особенности хронического цистита в столичном мегаполисе}

Н.А. Сайдакова, В.П. Стусь,

А.В. Шуляк, Н.В. Гавва,

Л.Н. Старцева

В работе представлены результаты анализа за 2008-2017 годы распространенности и заболеваемости хроническим циститом взрослого населения г. Киева на основе данных государственных, отраслевых статистических отчетов (Ф.Ф. № $12,20)$. Выделены два пятилетних периода, обоснованием для чего были известные территориальные изменения в стране; соответствующие показатели служили в качестве сравнения, что позволяло выявить особенности динамики изучаемых процессов.

В результате 10 -летнего наблюдения выявлено, что для г. Киева, который занимает второе место в структуре распространенности и заболеваемости хронического цистита в Украине, характерно уменьшение количества зарегистрированных больных (на 7,3\%) с одновременным увеличением впервые выявленных (на 15,6\%; на $25,6 \%$ мужчин и на $13,2 \%$ женщин) в отличие от общего их прироста в целом по стране (на $0,4 \%$ и на $2,8 \%$ соответственно). Показатели распространенности (на 100 тыс.) после повышения в первые пять лет сменяются снижением в следующем периоде (621,2 до 687,9 против 627,8 до 533,4$)$. Среди женщин они были большими в $3,5-4,8$ раза; в 2017 г. $-862,8$ против 176,6 среди мужчин. Особенность заболеваемости проявилась её увеличением среди женщин и мужчин за 2013-2017 годы на фоне уменьшения в предыдущие; в 2017 г. показатели на 100 тыс. достигали 88,5 ; среди женщин - 127,2, мужчин 41,5 .

Прослеженная ситуация повышения уровня заболеваемости хроническим циститом среди взрослого населения столицы при одновременном снижении распространенности позволяет оценивать её как результат оказанной адекватной специализированной помощи и, вместе с тем, указывает на необходимость изучения причин, негативных факторов, как основы совершенствования и внедрения профилактики заболевания.

Ключевые слова: хронический цистит, распространенность, заболеваемость, женщины, мужчины, столица. 